O. M. Velychko, DSc, T. B. Gordiyenko, DSc, L. V. Kolomiets, DSc

Odesa State Academia of Technical Regulation and Quality, Odesa

\title{
IMPROVED METHOD AND SOFTWARE-INSTRUMENTAL COMPLEX FOR GROUP EXPERT ASSESSMENT
}

An improved method of group expert evaluation is considered, which takes into account the competence of experts, and an algorithm for its implementation is proposed. An example of an assessment of the competence of experts in the field of metrological provision of measurements with the help of an improved method is given. The structural scheme of the proposed special software-instrumental complex for the implementation of group expert evaluation is described.

Keywords: group expert evaluation, competence, expert, evaluation criteria, software-instrumental complex.

\section{Introduction}

In order to obtain reliable assessments by means of group expert evaluation, it is first of all appropriate to approach the selection of the method and experts involved in the study. The general opinion of experts is obtained through the use of mathematical statistics in the processing of expert data obtained and verification of consistency. The simplest methods of expert evaluations are mainly used as components of more complex methods for evaluating complex systems. Most often in the practice of expert evaluation, a questionnaire is used, which allows to gather the opinion of experts with the least labor [1-3].

The expert data obtained should be checked for consistency. In the case of inconsistency data, it is necessary to analyze or reject this data, or to further harmonize the data by specifying the criteria or indicators used. In order to obtain reliable estimates of the group expert evaluation in any field of activity, it is necessary to select the most optimal method. Since these methods are based on various algorithms for the implementation of expert evaluation, the method chose needs to be refined for specific needs in a particular area [1-6].

\section{The aim and tasks of the study}

The most commonly used expert methods are quite simple and have their drawbacks [1-6]. Many papers on the application of expert methods describe the use of specially designed software. The software allows significantly increasing the productivity of the applied methods of expert evaluation and eliminating errors in calculations of the results $[7,8]$. The research was aimed at developing the most effective method and means for evaluating the competence of experts using scientifically-based criteria. There are many approaches that are used to address socioeconomic and other issues, but these approaches often fail to address purely technical issues.
For the achievement of the put aim next tasks decided:

- to improve the most effective method of group expert evaluation for certain tasks in the field of technical regulation, which makes it possible to take into account the level of competence of the involved experts;

- develop an implementation algorithm for improved method of group expert evaluation which takes into account the competence of experts;

- carry out estimation by use of the improved method in the field of metrological provision of measurements and to analyze the results;

- to develop an advanced software-instrumental complex for expert evaluation.

\section{Improved method of group expert evalua-} tion

The method of expert evaluation that is subject to improvement is described in $[1,9]$.

For realization of improved method calculate:

- average values $\bar{x}_{i}$ for each of $N$ analyzed questions ( $j$ from 1 to $N$ ), taking into account coefficient of competence (CC) for each of $M$ expert's, who participated in the evaluation:

$$
\bar{x}_{i}=\sum_{j=1}^{M} x_{j} \cdot k_{c j} / M,(i=1,2, \ldots, N)
$$

- reference value of expert evaluation $x_{\text {ref }}$ for all problem questions as simple average value for all analyzed questions (in balls):

$$
x_{\text {ref }}=\sum_{i=1}^{N} \bar{x}_{i} / N
$$

- degree of deviation of the estimated average balls $\bar{x}_{i}$ from the reference value $x_{\text {ref }}$ for each of the identified questions (in points):

$$
D_{i}=\bar{x}_{i}-x_{\text {ref }} .
$$


On the received values of the degree of deviation of the estimated average balls from the reference value, the ranking of the obtained values in order of decreasing $D_{i}$ is carried out.

In the future, calculate the indicators that characterize the consistency of the data received for the questions considered:

- Kendall consistency coefficient $W$, taking into account the coherent levels [1]:

$$
W=\frac{12 S}{M^{2}\left(N^{3}-N\right)-M \sum_{i=1}^{M} T_{i}},
$$

where: $\quad T_{i}=\sum_{q-1}^{Q}\left(t_{q}^{3}-t_{q}\right)$;

$S$ - sum of the squares of deviations from the average;

$T_{i}$ - total number of the same ranks for the $i$-th expert for all the questions that are being considered;

$t_{q}$ - number for the same rank for the $i$-th expert for all the questions that are being considered;

$Q$ - number of groups of the same ranks in the $i$-th expert on the questions being considered;

$q$ - same rank for the $i$-th expert for all the questions that are being considered;

- Pearson's $\chi^{2}$ agreement criterion, taking into account bound ranks:

$$
\chi^{2}=\frac{S}{M N(N+1)-\frac{1}{N-1} \sum_{i=1}^{M} T_{i}} .
$$

Analyze the obtained value of the Kendall consistency coefficient $W$ and conclude on the degree of consistency of data in accordance with the Margolin scale [1]. If necessary, adjust the balls values for certain related questions.

The obtained value based on Pearson's $\chi^{2}$ consent criterion for the confidence level of 0.05 is compared with the critical value $\chi^{2}>\chi_{\mathrm{T}(0,05 ; M-1)}^{2}$ for this confidence level.

In the case where the value of the criterion is less than the tabulated critical value, consideration of the correction of ball values for certain related questions is required.

The final step is to create list of issues for further detailed consideration and a list of rejected questions for further consideration and presentation of results on a special chart (lobe or histogram) with the application of the reference value of the expert assessment. To form a histogram with finite results, use the Pareto principle with drawing a Lorentz curve [1].

The algorithm for the implementation of the improved method of group expert evaluation which takes into account the competence of experts is given in Fig. 1. This algorithm can be easily implementted with the use of widespread mathematical software (for example, Microsoft Excel). The software allows selection of the most priority issues in certain industries from those that are defined for consideration by the expert group, as well as reject issues that are not of primary or no significance for further analysis.

3. An example of an estimation of the state of metrology provision of measurements by an improved method

On determination of metrology provision (MP) it is establishment and application of metrology norms and rules, and also development, making and application of technical equipment necessary for the achievement of unity and necessary exactness of the certain measuring. Important is reliable knowledge about the real condition of MP for measuring of certain physical value. One of useful facilities for permission of the marked question can become a group expert evaluation with bringing of experts from metrology, id est highly skilled specialistmetrologists.

The results of the assessment of the state of the MP for measuring the phase shift angle are shown in Fig. 2 and 3. Relative assessment is a relative value for a particular type of measurement from the maximum score ( 9 points), and the reference value is the arithmetic mean for all questions. 
1. Definition of the CC for each of the experts participating in the expert evaluation, on the basis of presented objective data

2. Compiling a list of $N$ problematic issues that need to be analyzed

3. Definition of scale balls for expert assessment of certain issues

4. Calculation of average values for each of the identified issues without/taking into account the

$\mathrm{CC}$ of each of the $M$ experts who participated in the assessment

5. Calculation of the reference value of the expert evaluation for all problematic issues as a simple average

6. Determine the degree of deviation of the estimated average values from the reference value for each of the identified issues and rank the resulting values in decreasing order

\section{$\downarrow$}

7. Calculations to establish consistency of expert data on the basis of calculating the Kendall consistency coefficient $W$

8. Conclusion on the degree of consistency of data based on the calculated value of the Kendall consistency coefficient $W$

9. Calculations to establish consistency data about experts on the basis of calculating the value of the criterion $\chi^{2}$

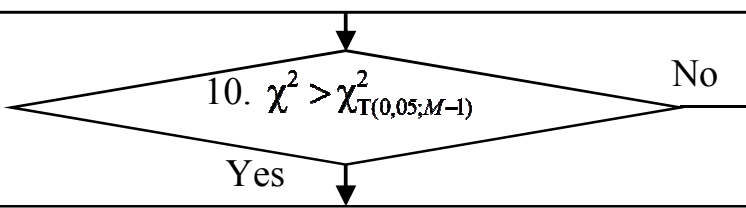

11. Ranking the resulting values for sub-questions in order of decreasing $D_{i}$ and applying the Pareto principle

12. Formation of the list of considered sub-questions for their further more detailed consideration with the presentation of it on a special chart.

Figure 1 - Algorithm for the implementation of the improved method of group expert evaluation which takes into account the competence of experts 


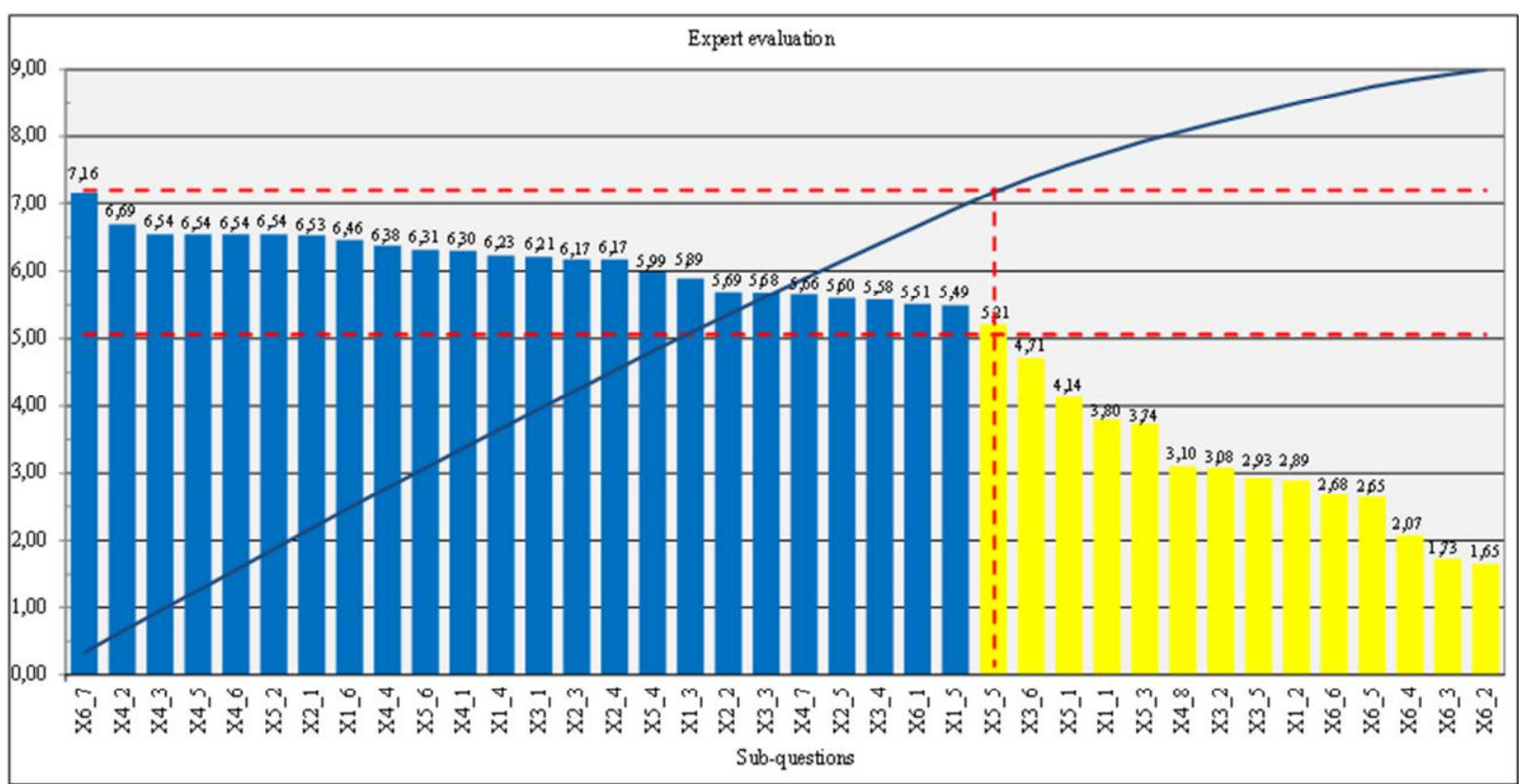

Figure 2 - Results of evaluation by an improved method for sub-questions based on the competence of experts from measurement of phase shift angle

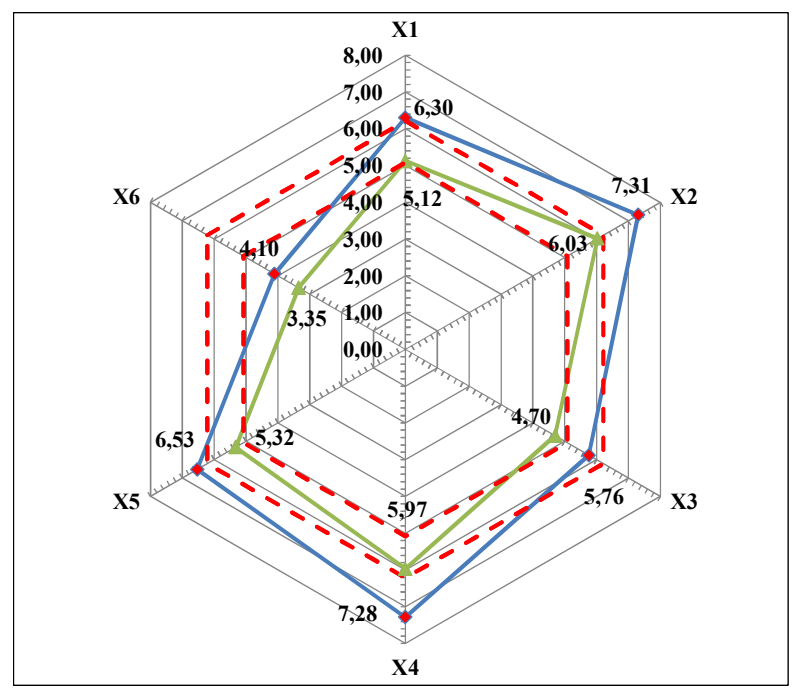

Figure 3 - Chart for the average points for questions without and based on the competence of experts from measurement of phase shift angle

The generalized assessment of the state of the MP measurements can be conditionally on the levels (graduations) given in Table 1.

The analysis of the results shows that 14 questions $(36 \%)$ are prioritized for further detailed analysis in order to make the necessary decisions, that is, comparing with the method that has been improved, no new priorities have been identified.

An analysis of the results shows that:

- values of Kendall consistency coefficient $W$ for measuring the phase shift angle is 0.44 that corresponds to the "middle" (from 0.37 to 0.64 according to Table 1) levels (Margolin's poor consistency);
- obtained value of Pearson's $\chi^{2}$ for measuring the phase shift angle is 19.45 which corresponds criterion the established requirements for the confidence level of $0.05\left(\chi^{2}>\chi_{\mathrm{T}(0,05 ; M-1)}^{2}=9.49\right)$.

Table 1

\begin{tabular}{|c|l|l|}
\hline $\begin{array}{c}\text { Levels } \\
\text { of MP }\end{array}$ & $\begin{array}{l}\text { Features of the state } \\
\text { of MP }\end{array}$ & $\begin{array}{c}\text { Average for all } \\
\text { questions }\end{array}$ \\
\hline High & $\begin{array}{l}\text { High scores of ex- } \\
\text { perts on most MP } \\
\text { issues }\end{array}$ & $\begin{array}{l}\text { more than } 0.7 \\
\text { from the maxi- } \\
\text { mum score }(9 \\
\text { points) }\end{array}$ \\
\hline Lverage & $\begin{array}{l}\text { The high and low } \\
\text { points of the ex- } \\
\text { perts were divided } \\
\text { on MP issues }\end{array}$ & $\begin{array}{l}\text { from } 0,3 \text { to } 0,7 \\
\text { of the maximum } \\
\text { score }\end{array}$ \\
\hline Low scores of ex- \\
$\begin{array}{l}\text { perts on most MP } \\
\text { issues }\end{array}$ & $\begin{array}{l}\text { less than } 0.3 \text { of } \\
\text { the maximum } \\
\text { score }\end{array}$ \\
\hline
\end{tabular}

\section{Improved software-instrumental complex for group expert evaluation}

In $[7,8,10]$ it was noted that there are certain peculiarities of application of software-instrumental means, which is connected with the based methods.

The flow diagram of the proposed special software-instrumental complex for conducting a group expert evaluation is shown in Fig. 4, where:

1 - module of task of set of competence criteria of technical expert for research of certain object and its numerical (balls) values;

2 - module of insertion of objective data on the set criteria for the set of competence $M$ experts that is compared; 


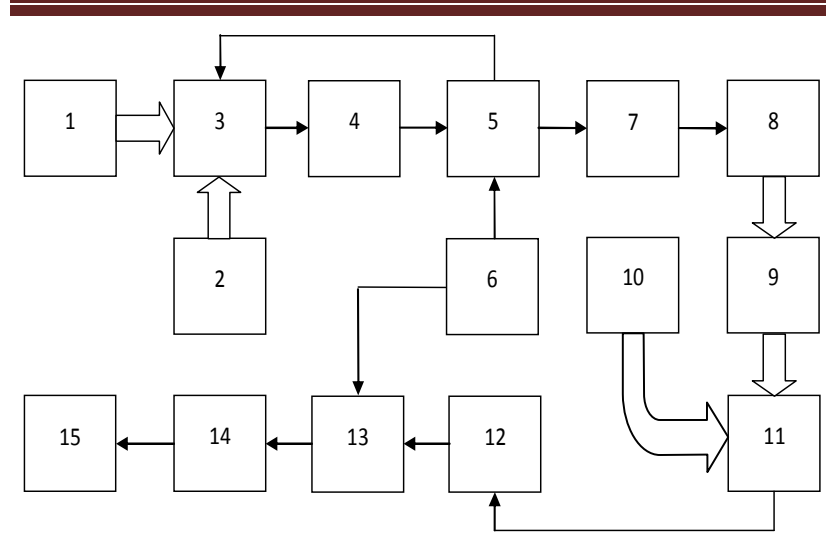

Figure 4 - Proposed special software-instrumental complex for group expert evaluation

3 - module of calculation of average values, relative average values, normalized average values numerical score and total of average value, total relative average value and the average normalized value for all $M$ technical experts according to all criteria;

4 - module of Kendall consistency coefficient calculation, taking into account related ranks and obtaining a conclusion on the established degree of data coherence;

5 - module for verifying the average normed for each expert on the compliance with Pearson's $\chi^{2}$ consent criterion, taking into account related ranks at a confidence level equal to 0.05 ;

6 - module of the set of critical values of $\chi^{2}$ for the confidence level is 0.05 ;

7 - module of ranking of got normalized average value for experts (values of competence) for a decrease with the rejection of normed averages for experts who do not meet the Pareto principle and displaying results on a special chart;

8 - module of forming of group of experts taking into account the got results in relation to consistency of data for realization of expert research of certain object;

9 - module specifies the set of problem issues $N$, which need to be analyzed, and the numerical (balls) values of the questions;

10 - module is intended for inputting the received questionnaires data from experts on the set list of problem issues $N$, which need to be analyzed;

11 - module for calculating average values for each of the identified issues without/taking into account the CC of each of the $M$ experts who participated in the assessment, the reference value of the expert assessment of all problem issues and the degree of deviation of the assessed mean values from the reference value for each of the identified issues;

12 - module of Kendall consistency coefficient calculation, taking into account related ranks and obtaining a conclusion on the established degree of data coherence;
13 - module for checking the average values for all sub-questions is estimated by all experts for compliance with Pearson's $\chi^{2}$ consent criterion, taking into account related ranks at a confidence level equal to 0.05

14 - module for ranking ball points obtained for sub-questions in order to reduce $D_{i}$, the application of the Pareto principle and displaying results on a special chart;

15 - module for the final formulation and the presentation in the special chart of the list of subquestions discussed for further detailed consideration.

Module 1 sets the plurality and numerical (ball) values of the criteria of evaluation competence of expert for to study a particular object in the chosen field of activity. In module 2 , objective data are entered according to the established criteria of evaluation competence of expert for a set of experts whose competence is assessed (compared).

With the help of module 3, calculations of average values, average relative and average normalized for the data of each technical expert, the total average value, the total relative average value and the average normalized score for all technical experts $M$ according to all criteria are performed.

Module 4 is intended to calculate the Kendall consistency coefficient, taking into account the related ranks and obtaining a conclusion on the established degree of consistency of the data. Module 5 is used to check the average normalized for each expert for the Pearson $\chi^{2}$ criterion, taking into account the bound ranks when compared with the critical values of $\chi^{2}$ for the confidence level of 0.05 . Module 6 contains sets of critical values of $\chi^{2}$ for a confidence level of 0.05 .

With the help of module 7, the ranked average normalized for experts (competency values) are ranked for a decrease with the rejection of the normed averages for experts who do not satisfy the Pareto principle and display the results on a special chart. With the help of module 8 , the final formation of a group of experts is carried out taking into account the results obtained for the coherence of the data for conducting expert research of certain objects in the chosen field of activity.

Module 9 defines the plural and numerical (balls) values of $N$ problem issues that need to be analyzed. In module 10 , the input of the received questionnaire data from experts in accordance with the set list of problem issues $N$, which need to be analyzed.

Module 11 is designed to calculate the average values for each of the identified issues without/ taking into account the $\mathrm{CC}$ of each of the $M$ experts who participated in the assessment; the reference value of the expert evaluation of all the issues as a 
simple average value and the degree of deviation of the assessed average values from the reference value for each of the identified issues.

Module 12 is intended to calculate the Kendall consistency coefficient, taking into account the related ranks and obtaining a conclusion on the established degree of data coherence. Module 13 is used to check the average values for all sub-questions by all evaluation of experts for compliance with Pearson's $\chi^{2}$ consent criterion, taking into account related ranks at a confidence level of 0.05 .

With the help of module 14, the rankings of the obtained ball values are made according to the subquestions in order of decreasing $D_{i}$, the application of the Pareto principle and displaying the results on a special chart. With the help of module 15, the final formation and presentation in the special chart of the list of considered sub-questions is carried out for further detailed consideration.

The application of the improved method and software for the group expert evaluation is not limited by the number of experts and the number of issues (factors) that need to be analyzed. This contributes to a more substantiated selection of the most priority areas for further consideration of problem issues in a particular area of activity. This increases the credibility of the evaluation and contributes to a more substantiated selection of the most priority areas for further consideration of problem issues in a particular area of activity.

\section{Conclusion}

An improved method of group expert evaluation has been developed, which has been tested on many objects in the field of metrology, in particular to establish the state of MP for measurement of phase shift angle.

It has been established that an important element of the practical application of the methods of group expert evaluation is the mandatory verification of the consistency of the obtained expert assessments. For this purpose, the most suitable means is to verify the consistency of expert data by applying the Kendall consistency coefficient and Pearson's $\chi^{2}$ consent criterion.

The proposed improved method and softwareinstrumental complex for group expert evaluation increases the reliability of the evaluation and has no limitations on the number of experts and the number of issues (factors) that need to be analyzed.

\section{Reference}

1. Velychko O. M. Methodologies of expert's competence evaluation and group expert evaluation [Text] / O. M. Velychko, T. B. Gordiyenko,
L. V. Kolomiets // Metallurgical and Mining Industry. - 2015. - № 2. - P. 262-271 (in Ukrainian).

2. Velychko O. The group expert evaluation of the metrological assurance of electric power measurements [Text] / O. Velychko, S. Karpenko // Journal of Physics: Conf. Series. - IOP Publication. Vol. 772, 2016. - 012043. - 6 p.

3. Velychko O. Evaluation of competence of the experts in field of metrology and instrumentations [Text] / O. Velychko, T. Gordiyenko // XXI IMEKO World Congress "Measurement in research and industry". Prague, Czech Republic, 2015. - 5 p.

4. Kolpakova T. A. Determination of competence of experts at the acceptance of group decisions [Text] / T. A. Kolpakova // Radio electronics, informatics, management. - 2011. - № 1. - P. 40-43 (in Russian).

5. Velychko O. N. Evaluation of experts competence on the measurement of electrical power using the method of analytic hierarchy [Text] / O. N. Velychko, T. B. Gordienko, S. R. Karpenko, L. V. Kolomiets // Metallurgical and Mining Industry. -2016 . - № 11. - P. 70-76.

6. Meimei Xia. Consistency and consensus improving methods for pairwise comparison matrices based on Abelian linearly ordered group [Text] / Meimei Xia, Jian Chen // Fuzzy Sets and Systems. Vol. 266, 2015. - P. 1 - 32

7. Velychko O. M. Special software for experts evaluation [Text] / O. M. Velychko, S. R. Karpenko, T. B. Gordiyenko, L. V. Kolomiets // Metallurgical and Mining Industry. - 2015. - № 7. - P. 401 - 407.

8. Velychko O. M. Hardware-software complexes for evaluation of competence level of experts [Text] / O. M. Velychko, T. B. Gordiyenko, L. V. Kolomiets // Metallurgical and Mining Industry. 2015. - № 7. - P. 396 - 401.

9. Gordiyenko T. B. Methodologies of expert's competence evaluation using the method of analytic hierarchy [Text] / T. B. Gordiyenko, O. M. Velychko // Metallurgical and Mining Industry. - 2014. - № 2. - P. 86 - 89 (in Ukrainian).

10. Velychko O. M. Special software for experts evaluation [Text] / O. M. Velychko, S. M. Shevkun, S. R. Karpenko // Information processing systems. Kharkiv. - 2015. - Вип. 6 (131). - С. 21-24 (in Ukrainian).

Надійшла до редакиії 02.06.2017

Рецензент: д.т.н., проф. Братченко Г. Д., Одеська державна академія технічного регулювання та якості, м. Одеса. 
О. Н. Величко, д.т.Н., Т. Б. Гордиенко, д.т.н., Л. В. Коломиец, д.т.н.

\section{УСОВЕРШЕНСТВОВАННЫЙ МЕТОД И ПРОГРАММНО-ИНСТРУМЕНТАЛЬНЫЙ КОМПЛЕКС ДЛЯ ГРУППОВОГО ЭКСПЕРТНОГО ОЦЕНИВАНИЯ}

Рассмотрен усовершенствованный метод группового экспертного оценивания, который учитывает компетентность экспертов, и предложен алгоритм его реализачии. Приведен пример оченки компетентности экспертов в сфере метрологического обеспечения измерений с помощью усовершенствованного метода. Описана структурная схема предлагаемого специального программноинструментального комплекса для осуществления группового экспертного оценивания.

Ключевые слова: групповое экспертное оченивание, компетентность, эксперт, критерии оценивания, программно-инструментальный комплекс.

О. М. Величко, д.т.н., Т. Б. Гордієнко, д.т.н., Л. В. Коломієць, д.т.н.

\section{УДОСКОНАЛЕНИЙ МЕТОД І ПРОГРАМНО-ІНСТРУМЕНТАЛЬНИЙ КОМПЛЕКС ДЛЯ ГРУПОВОГО ЕКСПЕРТНОГО ОЦІНЮВАННЯ}

Розглянуто удосконалений метод групового експертного оиінювання, який враховує компетентність експертів, та запропоновано алгоритм його реалізаџіï. Наведено приклад оцінювання компетентності експертів в сфері метрологічного забезпечення вимірювань за допомогою удосконаленого методу. Описано структурну схему пропонованого спеціального програмно-інструментального комплексу для здійснення групового експертного оцінювання.

Ключові слова: групове експертне оцінювання, компетентність, експерт, критерії оцінювання, програмно-інструментальний комплекс.

\section{УДК 330.2.}

Н. О. Ботвіна, д.е.н., Н. С. Згадова, к.е.н., М. В. Кравченко, к.е.н.

Одеська державна академія технічного регулювання та якості, м. Одеса

\section{МЕНЕДЖМЕНТ РЕГУЛЮВАННЯ ТА ЯКОСТІ КОНКУРЕНТОСПРОМОЖНОСТІ НА ПІДПРИЕМСТВАХ АПК}

У статті висвітлені проблеми менеджменту регулювання і якості конкурентоспроможності підприсмств АПК на внутрішньому і зовнішньому ринках. Сільське господарство, харчова і переробна промисловість залишаються неконкурентоздатними і потенційно незахищенними на різних рівнях законодавчої бази. Орієнтація на збільшення поточних доходів бюджетів усіх рівнів є руйнівною $i$ суперечливою, щчо призводить до занепаду сільського господарства. Запропоновано переглянути законодавчу базу оподаткування суб'єктів аграрної сфери, яка потребує вдосконалення, що сприятиме наближенню до світових аналогів.

Представлені в статті рекомендації щодо необхідності використання кількох сегментів зовнішніх ринків для експорту вітчизняних товарів поліпшать позиції конкурентоспроможної продукції.

Ключові слова: менеджмент, якість, агропромисловий комплекс, конкурентоспроможність, зовнішньоекономічна діяльність, зовнішній і внутрішній ринки.

Постановка проблеми. Регулювання та якість конкурентоспроможності продукції втілюється в новому або вдосконаленому продукті, нових технологіях - виробничих i управлінських, що відповідають досягненням світового науково-технічного прогресу [1].
Конкурентоспроможність $€$ показником ефективного відродження аграрної сфери України, іiї входження у світове господарство як рівноправного в економічному та науковотехнічному відношенні партнера. $\mathrm{y}$ ній висвітлюється прогрес технологій, організації 